\title{
SALESPERSON HUMAN CAPITAL INVESTMENT AND HETEROGENEOUS EXPORT ENTERPRISES PERFORMANCE
}

\author{
Yongliang $\mathrm{ZHAO}^{2}$, Weihua $\mathrm{RUAN}^{2}$, Yonghong JIANG ${ }^{1^{*}}$, Junnan $\mathrm{RAO}^{2}$ \\ ${ }^{1}$ Institute of Finance, Jinan University, Guangzhou, China \\ ${ }^{2}$ College of Economics, Jinan University, Guangzhou, China
}

Received 16 March 2018; accepted 25 September 2018

\begin{abstract}
This paper aims to study the impact of salesperson human capital investment on the export performance of heterogeneous enterprises in China. To distinguish the different effects on the staff level and the management level, we define the human capital investment for the overall salespersons as human capital investment I and the human capital investment for the sales managers as human capital investment II, respectively measured by the salary of the ordinary salespersons and the ratio of expenses to sales. We find that human capital investment I has a significant positive effect on export performance, while human capital investment II shows a "positive U-shaped" relationship with export performance. Considering the heterogeneity of enterprise, the positive effect of human capital investment I is more significant than that of human capital investment II in enterprises with high R\&D intensity. Moreover, with the improvement of technology intensity, both the promotion of human capital investment I and human capital investment II would generate greater influence on export performance.
\end{abstract}

Keywords: salesperson human capital investment, export performance, enterprise heterogeneity, business management, R\&D intensity, technology intensity.

JEL Classification: D24, F23, J24, L23, M54.

\section{Introduction}

The export competitiveness is closely related to the export performance for export enterprises engaged in international trade. With the deepening of international trade and the continuous improvement of the productivity level, enterprises no longer rely solely on the input of cheap labor force and natural resources to gain the export competitiveness. Instead, they pay more attention to exporting products with high knowledge intensity and high technology added value. As a result, enterprises engaged in labor-intensive industries are gradually shrinking around the world. They struggle to survive in the international market by transformation into technology-intensive enterprises so as to obtain a higher export competitive advantage.

${ }^{*}$ Corresponding author. E-mail: ojyh@jnu.edu.cn 
More and more types of export industries are covered by knowledge-intensive products and services, which rely on the input of high-quality human capital.

Schultz (1961) suggests that the knowledge and skill level of the labor force is a type of capital, that is, the human capital, which increases faster than other traditional forms of capital and constitutes the heterogeneity of economic system. The bulk of researches has illustrated that human capital is a crucial determinant of enterprise performance (Youndt, Snell, Dean, \& Lepak, 1996; Blundell, Dearden, Meghir, \& Sianesi, 1999; Toole \& Czarnitzki, 2009; Crook, Todd, Combs, Woehr, \& Ketchen, 2011; Holland, 2017; Volonté \& Gantenbein, 2016). Strategic human capital investments are capable of improving competitive advantages, and in turn, influence the scale and performance of enterprises. The same holds true for enterprises engaged in export activities. On the basis of the export data of 25 countries, Contractor and Mudambi (2008) find that the human capital investment significantly affects the exports of goods and services. Kadochnikov and Fedyunina (2017) investigate the effect of the human capital on the export performance in Russian regions using continuous time method and discrete time method, with the conclusion that the human capital affects the export performance and the time effects, which are more significant for enterprises with larger scale of export trade, fade over time. From the established researches we conclude that the strategy of human capital investment makes a great contribution to the export performance of enterprises.

Enterprises carrying out international trade are heterogeneous (Melitz, 2003). The enterprise heterogeneity is mainly reflected in the heterogeneity of the productivity, an important factor in forming the export competitiveness. The heterogeneity of the human capital affects the export performance, stemming in part from its impact on the productivity. Black and Lynch (1996) demonstrates that the human capital, including education level and employerprovided training, has a positive and significant effect on the productivity of establishments. Miller and Upadhyay (2000) show that the human capital positively affects the total factor productivity in both developed and developing countries on the basis of data from 83countries. From the enterprise perspective, Onkelinx, Manolova, and Edelman (2016) find that employee salary and employee training, embodying the human capital investment, has a positive correlation with the growth rate of the enterprise productivity. Furthermore, the rate of productivity is an important determinant of the scale of export trade. Aw and Hwang (1995) study the significant productivity difference between exporters and non-exporters in Taiwan and conclude that productivity differences contribute a lot to the export differences. Melitz (2003) investigates the relationship between the productivity and the international trade market, finding that enterprises with high productivity may enter the export market, while the less productive enterprises would be forced to exit and focus on the domestic market. That is to say, the increase of the human capital investment can promote the rate of productivity, thus contributing to the improvement of the export performance.

This paper clarifies the role of salesperson human capital investment in promoting the export performance of enterprises. As an important part of the human capital investment, salesperson ability determines whether the products can be traded to other enterprises or countries. Salesperson performance has a positive impact on the enterprise effectiveness (Babakus, Cravens, Grant, Ingram, \& Laforge, 1996). Considering enterprises engaged in export trade, the quality of the salespersons is directly related to whether the products can smoothly 
reach the export market and obtain the export earnings (Ruzo, Losada, Navarro, \& Díez, 2011; Helm \& Gritsch, 2014; Zeriti, Robson, Spyropoulou, \& Leonidou, 2014). Thus, the human capital of salespersons, including their individual abilities and professional sales training offered by enterprises, are essential to improving the competitiveness of export enterprises. Much of the existing research has focused on the relationship between human capital investment in sales managers and the enterprise performance (Axinn, 1988; Cavusgil \& Zou, 1994; Sousa, Ruzo, \& Losada, 2010; A. Rialp-Criado \& J. Rialp-Criado, 2018), while the role of human capital of the ordinary salesperson remains less explored. Therefore, our study divides the salesperson human capital investment into two parts, taking into account both the sales managers and the ordinary salespersons. One is named as human capital investment I for the overall salespersons, calculated by the salary of the ordinary salesperson, and the other is human capital investment II for the sales managers, measured by the ratio of expenses to sales.

The main objective of this study is to explain the logic mechanism of the relationship between the human capital investment of salespersons and the export performance of enterprises. Based on the micro-level sample data of A-share listed companies in Shenzhen and Shanghai of China, this study utilizes the panel data regression model to investigate the influence of the salesperson human capital investment on the export performance with the salary of the ordinary salesperson and the expense-to-sales ratio as proxy variables. Enterprise heterogeneity is also explored through subgroup analysis, from the perspectives of the R\&D intensity and the industry-specific technology intensity. Additionally, we provide policy suggestions for the salesperson management and the promotion of the export performance.

This paper complements the related literature in the following three ways. First, there is a large amount of research about the relationship between human capital and productivity (Barrio-Castro, López-Baz, \& Serrano-Domingo, 2002; Chang, Wang, \& Liu, 2016; Turner, Tamura, \& Mulholland, 2013; Kumar \& Kober, 2012; Bowlus \& Robinson, 2012; Pastore, 2013), and the impact of productivity on export (Söderling, 2000; Ricci \& Trionfetti, 2012; Yang \& Chen, 2012; Delgado, Farinas, \& Ruano, 2002; Rodrigue, 2014; Engel \& Procher, 2012). But studies specifically examine the effect of the human capital investment on export performance are relatively less. Our study contributes to the recent literature in this direction. Second, our work is based on the perspective of human capital investment of salespersons. In addition, we extend the existing model and construct a theoretical model exclusively aimed at the relationship between salesperson human capital investment and export performance, making a contribution to the specialized research on the human capital investment in salespersons. Third, our empirical analysis not only focuses on the basic relationship but also considers the different impacts for enterprises with different R\&D densities and technology densities. Thus this paper also extends the relevant researches about the impact of human capital investment on export in terms of enterprise heterogeneity.

The remainder of this paper is outlined as follows: Section 1 presents the theoretical model. Section 2 describes the variables and data sources. Section 3 shows the empirical strategy and results, considering enterprises with heterogeneous R\&D densities and technology densities. Finally, we summarize the major findings and provide some recommendations. 


\section{Theoretical model}

The heterogeneity of enterprises is mainly reflected in the difference in productivity, which will affect the export activities of enterprises (Melitz, 2003). The human capital investment is an essential factor that determines the export performance of enterprises, as the human capital can affect the export performance through its impact on the productivity of enterprises (Onkelinx et al., 2016; Bapna, Langer, Mehra, Gopal, \& Gupta, 2013; Georgiadis \& Pitelis, 2016). Therefore, increasing the human capital investment plays an important role in raising the productivity of enterprises. This study draws on the theoretical model of Akgul (2015), which demonstrates the influence of the heterogeneity of enterprise productivity on the export trade flow. Then we construct a theoretical model to describe the relationship between the human capital investment in salespersons and the export performance of enterprises. Additionally, we explain the logical impact mechanism of the productivity heterogeneity generated by the salesperson human capital investment and the export performance.

For export enterprises, the value of their export trade flows, which is equivalent to the export trade volume, refers to the product of the demand of the target market for exported products and the corresponding prices in the target market. The export trade volume is expressed as follows:

$$
M_{h r s}=\sum_{w} \int_{\varphi_{h r}^{*}}^{\infty} p_{w h r s}\left(\varphi_{h r}\right) q_{w h r s}\left(\varphi_{h r}\right) v\left(\varphi_{h r}\right) d \varphi,
$$

where $r$ captures the exporter and $s$ captures the importer of goods in the target market. $h$ is the industry to which the export products belong, assuming that a single enterprise exports goods only in one industry. $w\left(w \in \Omega_{h r}\right)$ represents the type of products included in industry $h$, and $\Omega_{h r}$ is the total types of goods in industry $h$ produced by the exporter. $\varphi_{h r}^{*}$ denotes the productivity threshold which determines the enterprise export. $p_{w h r s}$ is the target market price of the export product $w$ in the industry $h$, the value of which is related to the enterprise productivity, and the expression is as follows:

$$
p_{w h r s}\left(\varphi_{h r}\right)=\frac{\sigma_{h}}{\sigma_{h}-1} \frac{\tau_{w h r s} c_{w h r}}{\varphi_{h r}},
$$

where $\sigma_{h}$ is the substitution elasticity of products in the industry $h, \frac{\sigma_{h}}{\sigma_{h}-1}$ declines with the increase of $\sigma_{h}$. That is, the greater the substitution elasticity of the export products in the industry $h$, the higher the homogeneity among the products and the stronger competition in the industry $h$, thus the prices of products in the industry $h$ will be reduced to meet the needs of consumers in the target market. $\tau_{w h r s}$ captures the transport cost for a unit of product $w$ in the exporting process, the value of which is relatively stable. $c_{w h r}$ refers to the variable cost for a unit of product $w$, and $\varphi_{h r}$ represents the productivity of export enterprise in the industry $h$.

$q_{w h r s}\left(\varphi_{h r}\right)$ is the quantity of product $w$ belonging to industry $h$, connected with the productivity of enterprises. The expression is as follows:

$$
q_{w h r s}=\frac{p_{w h r s}^{-\sigma_{h}}\left(\varphi_{h r}\right)}{P_{h s}^{1-\sigma_{h}}\left(\varphi_{h r}\right)} Y_{h s}\left(\varphi_{h r}\right),
$$


where $P_{h s}$ is the price index of goods in the industry $h$ for the target market. $Y_{h s}$ is the total demand of the target market for goods exported by the enterprise in industry $h$, equivalent to the market size of goods in industry $h$ occupied by the exporter. $P_{h s}$ and $Y_{h s}$ are expressed as follows:

$$
\begin{gathered}
P_{h s}=\left[\sum_{r} \int_{w} p_{w h r s}^{1-\sigma_{h}}\left(\varphi_{h r}\right) d w\right]^{\frac{1}{1-\sigma_{h}}} ; \\
Y_{h s}=\int_{w} p_{w h r s}\left(\varphi_{h r}\right) q_{w h r s}\left(\varphi_{h r}\right) d w,
\end{gathered}
$$

where $v\left(\varphi_{h r}\right)$ refers to the distribution function for the productivity of the export enterprise, and the expression is as follows:

$$
v\left(\varphi_{h r}\right)=\frac{g\left(\varphi_{h r}\right)}{1-G\left(\varphi_{h r}^{*}\right)},
$$

where $\varphi_{h r}>\varphi_{h r}^{*}, g\left(\varphi_{h r}\right)$ is the density function of the enterprise productivity, and $G\left(\varphi_{h r}^{*}\right)$ refers to the cumulative distribution function of the enterprise productivity. This study assumes that the enterprise productivity follows Pareto distribution and the enterprise productivity $\varphi_{h r}$ is greater than the minimum $\varphi_{h r, \min }$. The parameter constraint is set to $\gamma_{h}>\sigma_{h}-1$. The formulas of the density function and the cumulative distribution function of the enterprise productivity are as follows:

$$
\begin{gathered}
g\left(\varphi_{h r}\right)=\gamma_{h} \frac{\varphi_{h r, \min }^{\gamma_{h}}}{\varphi_{h r}^{\gamma_{h+1}}}, \\
G\left(\varphi_{h r}\right)=1-\left(\varphi_{h r, \min } / \varphi_{h r}\right)^{\gamma_{h}} .
\end{gathered}
$$

Plug equation (7) into equation (6) and get the following equation

$$
v\left(\varphi_{h r}\right)=\frac{\gamma_{h}\left(\varphi_{h r}^{*}\right)^{\gamma_{h}}}{\varphi_{h r}^{\gamma_{h+1}}}
$$

where $\varphi_{h r}>\varphi_{h r}^{*}, \gamma_{h}>\sigma_{h}-1$, and $\varphi_{h r}=\mu\left(k_{h r}, H\left(\right.\right.$ salary $\left.\left._{h r-}, s r r_{h r_{-}}\right)\right)$, noting that only the factors that have the greatest impact on the enterprise productivity are considered. $k_{r}$ refers to the physical capital per unit labor force, reflecting the technological innovation capability of enterprises. $H\left(\right.$ salary $\left._{h r_{-},}, s r r_{h r}\right)$ captures the human capital investment per unit labor force, which is determined by the salary level of ordinary salesperson and the sales expense ratio.

Combing the relationship between the human capital investment and the enterprise productivity and the relationship between the enterprise productivity and the export volume, we obtain the theoretical model of the impact of the human capital investment on the export performance, which is expressed as follows:

$$
M_{h r s}=\sum_{w} \int_{\varphi_{h r}^{*}}^{\infty} \frac{p_{w h r s}^{1-\sigma_{h}}\left(\varphi_{h r}\right) \int_{w} p_{w h r s}\left(\varphi_{h r}\right) q_{w h r s}\left(\varphi_{h r}\right) d w v\left(\varphi_{h r}\right) d \varphi}{\sum_{r} \int_{w} p_{w h r s}^{1-\sigma_{h}}\left(\varphi_{h r}\right) d w}
$$

where $\varphi_{h r}=\mu\left(k_{h r}, H\left(\right.\right.$ salary $\left.\left._{h r-}, s r r_{h r-}\right)\right)$. 
According to the above model, we can see that enterprises try to attract and retain experienced and skilled employees with a higher level of education, by offering a competitive salary $H\left(\right.$ salary $\left._{h r_{-}}, s r r_{h r}\right)$, which is the main way of human capital investment. Human capital investment determines the quality of human capital (Becker, 1962). Salespersons play a crucial part in getting products to the market, making consumers familiar with the corporate products, and creating revenue for the enterprise. The compensation of salespersons is linked to their sales performance. Increasing the salary of salespersons not only boosts their enthusiasm but also prompts them to enhance their knowledge and skills for better sales performance, which benefits the improvement of the export performance of enterprises. Based on the above theoretical analysis, this study argues that salesperson human capital investment plays a positive role in promoting the export performance of enterprises.

\section{Variables and data}

\subsection{Export performance}

This study employs the ratio of the income from overseas business and the income from the main business to represent the export performance, where the income from the overseas business is the revenue generated by an enterprise's export trade and doesn't involve the business income related to overseas investment. We consider the export performance of Ashare companies listed on the Shanghai Stock Exchange and the Shenzhen Stock Exchange between 2011 and 2015, and the sample data is drawn from Wind database. In order to eliminate the influence of inflation, the real export performance is adopted by using the provincial consumer price index (CPI) of enterprises, obtained from the Chinese National Bureau of Statistics.

\subsection{Human capital investment}

Our measure of human capital investment is composed of two indicators based on different perspectives. One is the salary of the ordinary salesperson, which represents the human capital investment in overall salesperson, the other is the ratio of expenses to sales, signifying human capital investment in sales managers.

It is commonly believed that well-educated and experienced employees are supposed to obtain higher salaries than others, which attributes to the differentiation of human capital investment (Blundell et al., 1999; Schmid \& Altfeld, 2018). The accumulation of human capital implies receiving education and professional training at great cost, thus enterprises are responsible for paying proportionable compensation for the use of human capital of employees (L. Kozioł, W. Kozioł, Wojtowicz, \& Pyrek, 2014). Onkelinx et al. (2016) apply employee compensation and training cost as instrumental variables of human capital investment and illustrate that human capital investment has a positive association with the labor productivity. Therefore, we employ the salary of the overall salesperson as a measure of the human capital investment in overall salespersons. The salesperson salary applied in this study consists of the basic salary and the performance salary. Moreover, we introduce the CPI index to obtain the real salary of the overall salesperson. 
Competitive sales managers are always crucial for enterprises to maintain competitive positions in the market. Their marketing management skills are undoubtedly an important component of the human capital, which can improve the effectiveness of overseas business marketing strategies (Griffith \& Hoppner, 2013; Chng, Shih, Rodgers, \& Song, 2015; Olson, Slater, Hult, \& Kai, 2018). Channel development and promotion activities are important parts of marketing strategies. They often take various forms, including home visits, advertising, staff promotions and so on. The resulting sales expenses can reflect the effectiveness of marketing programs, which are planned by sales managers. The more effective the marketing program is, the more competent and experienced the sales manager is (Hawes, Jr, Schlacter, \& Wolfe, 1995; Akdeniz, Gonzalez-Padron, \& Calantone, 2010). In other words, the effectiveness of marketing programs positively relates to the human capital of sales managers. Besides, the implementation of effective marketing programs promotes the growth of exports (Koh \& Robicheaux, 1988; Leonidou, Katsikeas, \& Samiee, 2004). Accordingly, this study introduces the ratio of sales expenses to main business income, the ratio of expenses to sales for short, to measure the human capital investment in sales managers.

Our measure of sales expenses includes all the costs of sales activities except salesperson salaries, such as advertising expenses, social entertainment expenses, traveling expenses, and sales skills training fee. The ratio of expenses to sales is calculated as the proportion of sales expenses to main business income, and the CPI index is also applied to acquire the real sales expense rate.

\subsection{Enterprise characteristics}

Several enterprise-level control variables are employed to capture other enterprise characteristics that may have an impact on the export performance, including R\&D intensity, total factor productivity (TFP), enterprise size, enterprise age, and industry. We use the ratio of $\mathrm{R} \& \mathrm{D}$ expenses and the main business income to measure the R\&D intensity. Likewise, the ratio is adjusted by the CPI index to eliminate the effects of inflation.

The TFP of enterprise level is calculated with the OP method (Olley \& Pakes, 1992), in view of the endogeneity problems and the loss of valid information generated by OLS and FE method (Demmel, Máñez, Rochina-Barrachina, \& Sanchis-Llopis, 2017). The industrial added value is determined by the sum of the main business income of the year and the yearly increment of the inventory value. Moreover, we introduce the ex-factory price index of industrial products for each province or municipality to adjust the industrial added value. Using the production method, the intermediate investment is calculated by the main business costs plus the corporate expenses and minus the sum of the current fixed assets depreciation and the labor remuneration, determined by the payroll payable. And the fixed assets depreciation is expressed by the product of the net value of the fixed assets in the previous period and the depreciation rate, which is set as $15 \%$ (Wang \& Yao, 2003). The fixed investment in this period refers to the added value of net fixed assets in this period relative to that of the previous period plus the depreciation of fixed assets in the current period. And the price index on fixed asset investment in each province or municipality is adapted to deflate the fixed investment. Considering the existence of a negative value of the fixed investment, this study 
employs the intermediate investment as a substitute for the fixed investment before deflation. The capital stock is represented by the net fixed assets, using the price index of fixed asset investment to obtain the real value. The labor input refers to the number of employees in the enterprise. The enterprise life expresses the difference between the year of establishment and the current year. The exit variable reflects the survival and performance of the enterprise. The nature of the enterprise is a dummy variable, which is 1 for state-owned enterprises and 0 for non-state-owned enterprises.

Table 1 summarizes the 9 variables employed in the following empirical analysis and their calculating methods.

Table 1. Variables and explanations

\begin{tabular}{|c|c|c|}
\hline Variable & Definition & Calculation \\
\hline \multicolumn{3}{|c|}{ Dependent variable } \\
\hline$e e_{-}$ & $\begin{array}{l}\text { Enterprise export } \\
\text { performance }\end{array}$ & $\begin{array}{l}\text { (Overseas business income / main business income) / regional } \\
\text { CPI deflator }\end{array}$ \\
\hline \multicolumn{3}{|c|}{ Independent variables } \\
\hline salary_ & $\begin{array}{l}\text { Salary level of sales- } \\
\text { person }\end{array}$ & Salary of salesperson / regional CPI deflator \\
\hline$s r r_{-}$ & $\begin{array}{l}\text { Ratio of expenses to } \\
\text { sales }\end{array}$ & (Sales expenses / main business income) / regional CPI deflator \\
\hline$s r r 2$ & $\begin{array}{l}\text { Square of the ratio of } \\
\text { expenses to sales }\end{array}$ & Square of $s r r_{-}$ \\
\hline \multicolumn{3}{|c|}{ Control variables } \\
\hline$r d_{-}$ & $\mathrm{R} \& \mathrm{D}$ intensity & (R\&D expenses / main business income) / regional CPI deflator \\
\hline$t \mathrm{fp}$ & $\begin{array}{l}\text { Total factor } \\
\text { productivity }\end{array}$ & Total Factor Productivity Calculated Using the OP Method \\
\hline size & Enterprise size & The natural logarithm of the total number of employees \\
\hline age & Enterprise age & The year of investigation - The year of establishment +1 \\
\hline ind & $\begin{array}{l}\text { Industry to which the } \\
\text { enterprise belongs }\end{array}$ & Dummy variable, manufacturing $=1$, non-manufacturing $=0$ \\
\hline
\end{tabular}

Considering that different R\&D intensity of enterprises and different technology intensity of industries to which enterprises belong to will lead to distinct impacts of the human capital investment on the export performance, it is necessary to distinguish the enterprises in accordance with their R\&D intensity and technology intensity. The following Table 2 and Table 3 respectively give the structure and characteristics of different types of enterprise research samples.

As is shown in the tables, the salesperson salary (salary_) and sales expense rate (srr_) of the enterprises with high R\&D intensity and technology-intensive enterprises are both higher than that of enterprises with low R\&D intensity and labor-intensive enterprises. The distributions of the export performance and the control variables are relatively uniform among the enterprises with different R\&D intensity and different technology-intensity, except that the R\&D intensity of enterprises with high R\&D intensity are obviously higher than that of enterprises with low $\mathrm{R} \& \mathrm{D}$ intensity. 
Table 2. The structure and characteristics of enterprise samples with different $R \& D$ intensity

\begin{tabular}{|c|c|c|c|c|c|c|c|c|c|}
\hline $\mathrm{R} \& \mathrm{D}$ intensity & & $e e_{-}$ & salary $_{-}$ & $s r r_{-}$ & $s r r 2_{-}$ & $r d_{-}$ & $t f p$ & size & age \\
\hline \multirow{5}{*}{$\begin{array}{l}\text { High R\&D } \\
\text { intensity }\end{array}$} & $\mathrm{N}$ & 357 & 357 & 357 & 357 & 357 & 357 & 357 & 357 \\
\hline & mean & 0.1778 & 9.2098 & 0.1153 & 0.0183 & 0.2255 & 5.0191 & 2.9430 & 15 \\
\hline & sd & 0.2027 & 26.2569 & 0.0712 & 0.0179 & 0.0705 & 0.4981 & 0.3366 & 4 \\
\hline & $\min$ & 0.0004 & 0.0009 & 0.0151 & 0.0002 & 0.1517 & 3.7369 & 2.1492 & 10 \\
\hline & $\max$ & 0.6175 & 214.2711 & 0.2455 & 0.0603 & 0.4886 & 6.4323 & 3.6592 & 24 \\
\hline \multirow{5}{*}{$\begin{array}{l}\text { Low R\&D } \\
\text { intensity }\end{array}$} & $\mathrm{N}$ & 2968 & 2968 & 2968 & 2968 & 2968 & 2968 & 2968 & 2968 \\
\hline & mean & 0.1353 & 2.7400 & 0.0455 & 0.0051 & 0.0034 & 7.1588 & 3.6480 & 16 \\
\hline & sd & 0.1614 & 3.8812 & 0.0548 & 0.0133 & 0.0022 & 1.3636 & 0.5270 & 5 \\
\hline & $\min$ & 0.0009 & 0.0077 & 0.0004 & 0.0000 & 0.0000 & 4.1032 & 2.3385 & 2 \\
\hline & $\max$ & 0.8783 & 23.7947 & 0.3374 & 0.1138 & 0.0075 & 10.6566 & 5.0054 & 33 \\
\hline \multirow{5}{*}{ Total } & $\mathrm{N}$ & 3325 & 3325 & 3325 & 3325 & 3325 & 3325 & 3325 & 3325 \\
\hline & mean & 0.2027 & 5.7773 & 0.0610 & 0.0070 & 0.0374 & 6.1605 & 3.3709 & 15 \\
\hline & sd & 0.2037 & 22.4263 & 0.0573 & 0.0164 & 0.0340 & 1.1887 & 0.4822 & 5 \\
\hline & $\min$ & 0.0001 & 0.0001 & 0.0004 & 0.0000 & 0.0000 & 3.3538 & 2.1335 & 1 \\
\hline & $\max$ & 0.9422 & 493.0277 & 0.5016 & 0.2516 & 0.4886 & 11.7980 & 5.2923 & 35 \\
\hline
\end{tabular}

Table 3. The structure and characteristics of enterprise samples with different technology intensity

\begin{tabular}{|c|c|c|c|c|c|c|c|c|c|}
\hline Tech intensity & & $e e_{-}$ & salary_ & $s r r_{-}$ & $s r r 2$ & $r d_{-}$ & $t f p$ & size & age \\
\hline \multirow{5}{*}{$\begin{array}{l}\text { Tech- } \\
\text { intensive }\end{array}$} & $\mathrm{N}$ & 295 & 295 & 295 & 295 & 295 & 295 & 295 & 295 \\
\hline & mean & 0.1866 & 8.6725 & 0.0637 & 0.0079 & 0.0434 & 6.2039 & 3.3604 & 16 \\
\hline & sd & 0.2167 & 26.6538 & 0.0622 & 0.0171 & 0.0560 & 1.4113 & 0.5413 & 6 \\
\hline & $\min$ & 0.0003 & 0.0030 & 0.0037 & 0.0000 & 0.0001 & 3.5982 & 2.1335 & 4 \\
\hline & $\max$ & 0.7735 & 214.2711 & 0.3551 & 0.1261 & 0.4886 & 10.3019 & 4.7424 & 33 \\
\hline \multirow{5}{*}{$\begin{array}{l}\text { Labor- } \\
\text { intensive }\end{array}$} & $\mathrm{N}$ & 3030 & 3030 & 3030 & 3030 & 3030 & 3030 & 3030 & 3030 \\
\hline & mean & 0.2043 & 5.4954 & 0.0607 & 0.0069 & 0.0368 & 6.1562 & 3.3720 & 15 \\
\hline & sd & 0.2023 & 21.9561 & 0.0569 & 0.0164 & 0.0310 & 1.1649 & 0.4761 & 5 \\
\hline & $\min$ & 0.0001 & 0.0001 & 0.0004 & 0.0000 & 0.0000 & 3.3538 & 2.1732 & 1 \\
\hline & $\max$ & 0.9422 & 493.0277 & 0.5016 & 0.2516 & 0.4126 & 11.7980 & 5.2923 & 35 \\
\hline \multirow{5}{*}{ Total } & $\mathrm{N}$ & 3325 & 3325 & 3325 & 3325 & 3325 & 3325 & 3325 & 3325 \\
\hline & mean & 0.2027 & 5.7773 & 0.0610 & 0.0070 & 0.0374 & 6.1605 & 3.3709 & 15 \\
\hline & sd & 0.2037 & 22.4263 & 0.0573 & 0.0164 & 0.0340 & 1.1887 & 0.4822 & 5 \\
\hline & $\min$ & 0.0001 & 0.0001 & 0.0004 & 0.0000 & 0.0000 & 3.3538 & 2.1335 & 1 \\
\hline & $\max$ & 0.9422 & 493.0277 & 0.5016 & 0.2516 & 0.4886 & 11.7980 & 5.2923 & 35 \\
\hline
\end{tabular}

It should be noted that there is a minimum of 0.0000 for the $\mathrm{R} \& \mathrm{D}$ density ( $r d_{-}$) of an enterprise. That's because the $\mathrm{R} \& \mathrm{D}$ density is calculated by dividing the ratio of the $\mathrm{R} \& \mathrm{D}$ expenses to the main business income and the CPI deflator of the province or municipality to which the enterprise belongs, making the value of the R\&D density ( $r d \_$) value rather small. 
As the value is supposed to be rounded off to four decimal places in classified statistics, there will be the value of 0.0000 under some circumstances, which the actual value is employed for the empirical analysis.

Since the collinearity between the independent variables will affect the reliability of the regression results, it is necessary to test whether the collinearity among the independent variables is within the acceptable range. The VIF values of the independent variables are given in Table 4. It can be seen that most of the independent variables have VIF values less than 5 and the VIF values of $s r r_{-}$and $s r r 2_{-}$are less than 10 . Therefore, the collinearity degree among the independent variables of this study is acceptable.

Table 4. VIF values of the independent variables

\begin{tabular}{|l|c|c|c|c|c|c|c|c|c|}
\hline Variable & salary & $s r r_{-}$ & $s r 2_{-}$ & $r d_{-}$ & $t f p$ & size & age & ind & Mean VIF \\
\hline VIF & 1.29 & 6.22 & 5.83 & 1.19 & 3.68 & 3.22 & 1.10 & 1.01 & 2.94 \\
\hline
\end{tabular}

\section{Empirical strategy and results}

\subsection{Empirical strategy}

Based on the logical mechanism of the human capital investment on export performance above, we choose the explanatory variables and explanatory variables and their related control variables. The following linear regression model is given to represent the relationship between variables, where $X$ denotes the control variables.

$$
\begin{gathered}
e e_{-}=\beta_{0}+\alpha_{1} \text { salary }+\alpha_{2} X+\varepsilon_{1} ; \\
e e_{-}=\beta_{1}+\alpha_{3} s r r_{-}+\alpha_{4} X+\varepsilon_{2} ; \\
e e_{-}=\beta_{2}+\alpha_{5} s r r_{-}+\alpha_{6} s r 2_{-}+\alpha_{7} X+\varepsilon_{3} ; \\
e e_{-}=\beta_{3}+\alpha_{8} \text { salary }+\alpha_{9} s r r_{-}+\alpha_{10} s r r 2_{-}+\alpha_{11} X+\varepsilon_{4} .
\end{gathered}
$$

\subsection{Results of baseline estimation}

This study adopts the salary level of the salesperson (salary_) and the ratio of expenses to sales (srr_), which reflect the level of salesperson human capital investment, as explanatory variables. By setting different combinations of explanatory variables, we observe the individual and joint explanatory power of indicators. The coefficient direction and significance of the control variables in the eight regression equations are all consistent with expectations, as shown in Table 5, indicating that the regression results of this study are robust and reliable.

The regression results show that there is a significant positive relationship between the salary level of the ordinary salesperson and the export performance of enterprises, demonstrating that increasing the input of human capital on the overall salespersons can improve the export performance of enterprises. The fundamental components of material sales compensation are basic salary and performance pay. These two types of remuneration account for 
a large proportion of the salesperson pay and are also most closely related to the export. Enterprises always employ competitive, high-pay investment strategies to attract highly skilled employees and increase motivation (Onkelinx et al., 2016; Slaughter, Ang, \& Boh, 2007). Similarly, salesperson salary not only reflects the skill level and sales experience richness of a salesperson but also on behalf of the degree to which the enterprise recognizes the salesperson's ability. In addition, the remuneration of salespersons is linked to their sales performance. On the one hand, increasing the salaries can increase the enthusiasm of salespersons. On the other hand, the higher salaries represent the better sales performance and the higher level of knowledge and skills, which enables salespersons to make a greater contribution for sales revenue increase and export trade growth of the enterprises.

Moreover, the ratio of expenses to sales, reflecting the level of human capital investment in sales managers, shows a "positive U-shaped" relationship with the export performance of enterprises. There is a critical value for the investment in sales expenses. When the sales expense ratio is less than this value, the improvement of the sales expense ratio will reduce the export performance. Only if the sales expense reaches a certain level so that the sales expense ratio exceeds the critical value, will the export performance improve with the increase of the sales expenses. That is to say, the impact of the sales expenses on the export performance has some of the timeliness.

When companies enter a new market or produce new products, they need to devote a certain amount of money to gain the consumer's demand for their products in the market, such as advertising and exhibition expenses for expanding product recognition rates and the cost of sending salespersons for field marketing and so on. At this stage, the popularity and the acceptance rate of consumers in the market of the enterprise products are low, thus the space for making a profit is little. Companies are supposed to actively explore the market and meet the needs of consumers in this period, with the main purpose of expanding the market, making the product more acceptable and preparing for the long-term development of the enterprise in that market (Morgan, Katsikeas, \& Vorhies, 2012). Enterprises invest a lot of resources, additionally, the liquidity of the enterprise staff is strong at this time. The profit of the enterprise is not enough to offset the increase of the sales expense rate so that the enterprise profit decreases with the increase of the sales expense rate, which leads to the reduction of the export performance.

As the initial investment of the enterprise continues to expand, the products are gradually recognized by the consumers in the market. The profit space and the market scale are constantly expanding, and the demand for the products of the consumers in the market gradually stabilizes. At this moment, the sales profit of the enterprise is enough to bear the input of sales expenses. The enterprise has already crossed the critical point for the direction of the impact of the sales expense rate on the export performance. Moreover, since the main investment phase of the marketing plan has achieved a success, the investment in the sales expenses gradually reduces and tends to be stable. Sustained and stable sales expenses meet the stable demand of consumers for the products on the market. The corporate profits increase, making the company's exports also increase accordingly. So the increase in sales expenses promotes the growth of the export performance. 
Table 5. Regression results of the impact factors of export performance

\begin{tabular}{|c|c|c|c|c|c|c|c|c|}
\hline \multicolumn{9}{|c|}{ Dependent variable: enterprise export performance (ee_) } \\
\hline $\begin{array}{c}\text { Inde- } \\
\text { pendent } \\
\text { variable }\end{array}$ & (1) & (2) & (3) & $(4)$ & (5) & (6) & (7) & $(8)$ \\
\hline \multirow{2}{*}{ salary } & & $0.0002^{*}$ & & & & $0.0002^{*}$ & $0.0002^{*}$ & $0.0002^{*}$ \\
\hline & & $(0.0001)$ & & & & $(0.0001)$ & $(0.0001)$ & $(0.0001)$ \\
\hline \multirow{2}{*}{ srr } & & & -0.1316 & & $-0.3936^{\star \star}$ & $-0.1367^{\star}$ & & $-0.4063^{\star *}$ \\
\hline & & & $(0.0817)$ & & $(0.1723)$ & $(0.0821)$ & & $(0.1726)$ \\
\hline \multirow{2}{*}{$\operatorname{srr} 2$} & & & & -0.1183 & $0.8411^{\star}$ & & -0.1246 & $0.8649^{*}$ \\
\hline & & & & $(0.2154)$ & $(0.4866)$ & & $(0.2164)$ & $(0.4902)$ \\
\hline$r d$ & $\begin{array}{l}0.2272^{\star *} \\
(0.1095)\end{array}$ & $\begin{array}{l}0.1857^{\star *} \\
(0.0862)\end{array}$ & $\begin{array}{l}0.1518^{\star *} \\
(0.0663)\end{array}$ & $\begin{array}{l}0.1657^{* *} \\
(0.0781)\end{array}$ & $\begin{array}{l}0.1791^{*} \\
(0.1017)\end{array}$ & $\begin{array}{l}0.1758^{*} \\
(0.1102)\end{array}$ & $\begin{array}{c}0.1852^{\star} \\
(0.1229)\end{array}$ & $\begin{array}{l}0.1736^{*} \\
(0.1191)\end{array}$ \\
\hline$t f p$ & $\begin{array}{c}0.1567^{\star * *} \\
(0.0093)\end{array}$ & $\begin{array}{c}0.1489^{\star * *} \\
(0.0471)\end{array}$ & $\begin{array}{c}0.1522^{\star * *} \\
(0.0262)\end{array}$ & $\begin{array}{c}0.1518^{\star * \star} \\
(0.0289)\end{array}$ & $\begin{array}{c}0.1325^{\star * *} \\
(0.0152)\end{array}$ & $\begin{array}{c}0.1388^{\star * *} \\
(0.0237)\end{array}$ & $\begin{array}{c}0.1291^{* * *} \\
(0.0266)\end{array}$ & $\begin{array}{c}0.1266^{* * *} \\
(0.0309)\end{array}$ \\
\hline size & $\begin{array}{c}0.0616^{*} \\
(0.0355)\end{array}$ & $\begin{array}{c}0.0598^{\star} \\
(0.0263)\end{array}$ & $\begin{array}{c}0.0583^{\star} \\
(0.0315)\end{array}$ & $\begin{array}{c}0.0508 \\
(0.0412) \\
\end{array}$ & $\begin{array}{c}0.0557 \\
(0.0489)\end{array}$ & $\begin{array}{c}0.0535 \\
(0.0406)\end{array}$ & $\begin{array}{c}0.0568^{\star} \\
(0.0312)\end{array}$ & $\begin{array}{c}0.0546^{\star} \\
(0.0317)\end{array}$ \\
\hline age & $\begin{array}{l}0.0332^{\star} \\
(0.0176)\end{array}$ & $\begin{array}{l}0.0351^{\star *} \\
(0.0165)\end{array}$ & $\begin{array}{l}0.0293^{*} \\
(0.0159)\end{array}$ & $\begin{array}{l}0.0288^{* *} \\
(0.0137)\end{array}$ & $\begin{array}{l}0.0314^{* *} \\
(0.0192)\end{array}$ & $\begin{array}{l}0.0282^{* *} \\
(0.0117)\end{array}$ & $\begin{array}{l}0.0256^{\star} \\
(0.0142)\end{array}$ & $\begin{array}{l}0.0303^{* *} \\
(0.0126)\end{array}$ \\
\hline ind & $\begin{array}{c}0.1061 \\
(0.1608)\end{array}$ & $\begin{array}{c}0.1203 \\
(0.1513)\end{array}$ & $\begin{array}{c}0.1245 \\
(0.1661)\end{array}$ & $\begin{array}{c}0.1301 \\
(0.1549)\end{array}$ & $\begin{array}{c}0.1241 \\
(0.1465)\end{array}$ & $\begin{array}{c}0.1419 \\
(0.1521)\end{array}$ & $\begin{array}{c}0.1242 \\
(0.1549)\end{array}$ & $\begin{array}{c}0.1336 \\
(0.1426)\end{array}$ \\
\hline \multirow{2}{*}{ Constant } & $0.2997^{* * *}$ & $0.2997^{\star * *}$ & $0.3093^{\star * *}$ & $0.3001^{* * *}$ & $0.3226^{* * *}$ & $0.3099^{* * *}$ & $0.3003^{\star * *}$ & $0.3236^{* * *}$ \\
\hline & $(0.0544)$ & $(0.0538)$ & $(0.0554)$ & $(0.0544)$ & $(0.0562)$ & $(0.0547)$ & $(0.0537)$ & $(0.0555)$ \\
\hline $\begin{array}{l}\text { Adjusted } \\
\mathrm{R}^{2}\end{array}$ & 0.0264 & 0.0269 & 0.0409 & 0.0297 & 0.0462 & 0.0431 & 0.0305 & 0.0492 \\
\hline $\mathrm{N}$ & 3325 & 3325 & 3325 & 3325 & 3325 & 3325 & 3325 & 3325 \\
\hline
\end{tabular}

Notes: ${ }^{*}, * *,{ }^{* *}$ respectively indicates significance at the $10 \%, 5 \%, 1 \%$ level. The values in the bracket are standard errors. The same below.

\subsection{Impact analysis based on R\&D intensity heterogeneity}

As is shown in Table 6, the coefficients of the sales expenses rate, which reflect the impact of salesperson human capital investment II on the export performance, are not significant in both enterprises with high $R \& D$ intensity and low $R \& D$ intensity. While the salary level of a salesperson, representing the salesperson human capital investment I, has a significant positive influence on the export performance no matter what type of R\&D intensity enterprises have. Furthermore, increasing salesperson human capital investment I leads to greater growth of export performance in enterprises with higher R\&D intensity. Matching the R\&D investment with the human capital investment can make R\&D investment contribute more to the technological progress of enterprises, avoiding the existence of negative impact of $R \& D$ investment on technological progress (Caselli, 2014; Ballot, Fakhfakh, \& Taymaz, 2001). The growth of technological progress is consistent with the improvement of enterprise productivity. What's more, the change of enterprise productivity is in the same direction as the change 
of export performance. For enterprises with high R\&D intensity, their products always own higher technical added value, which has a higher demanding level of the knowledge of salespersons. That is to say, a certain level of human capital investment on salespersons is ordered to match the $R \& D$ intensity, in order to transmit the innovative power of products to the consumers.

Table 6. Regression results of the impact of the salesperson human capital investment on the export performance of enterprises with different R\&D intensity

\begin{tabular}{|c|c|c|c|c|c|c|c|c|}
\hline \multicolumn{9}{|c|}{ Dependent variable: enterprise export performance (ee_) } \\
\hline & \multicolumn{4}{|c|}{ high $\mathrm{R} \& \mathrm{D}$ intensity } & \multicolumn{4}{|c|}{ low R\&D intensity } \\
\hline $\begin{array}{l}\text { Indepen- } \\
\text { dent vari- } \\
\text { able }\end{array}$ & $(1)$ & $(2)$ & (3) & (4) & (5) & (6) & (7) & (8) \\
\hline \multirow{2}{*}{ salary_ } & $0.0208^{\star * *}$ & & & $0.0206^{\star * *}$ & $0.0004^{\star \star}$ & & & $0.0004^{\star *}$ \\
\hline & $(0.0051)$ & & & $(0.0054)$ & $(0.0002)$ & & & $(0.0002)$ \\
\hline \multirow{2}{*}{$s r r_{-}$} & & -0.0714 & -0.4096 & -0.2445 & & -0.0027 & -0.1526 & -0.1704 \\
\hline & & $(0.3292)$ & $(1.1960)$ & $(1.0744)$ & & $(0.2658)$ & $(0.4620)$ & $(0.4748)$ \\
\hline \multirow{2}{*}{$s r r 2_{-}$} & & & 1.1265 & 0.4408 & & & 0.6314 & 0.7354 \\
\hline & & & $(3.4469)$ & $(2.7919)$ & & & $(0.9784)$ & $(0.9992)$ \\
\hline \multirow{2}{*}{ constant } & $0.5184^{* * *}$ & 0.1972 & 0.2095 & $0.5676^{\star *}$ & $0.2341^{\star *}$ & $0.2705^{\star *}$ & $0.2747^{\star *}$ & $0.2391^{\star *}$ \\
\hline & $(0.1797)$ & $(0.2676)$ & $(0.2691)$ & $(0.2320)$ & $(0.1107)$ & $(0.1159)$ & $(0.1148)$ & $(0.1107)$ \\
\hline $\begin{array}{l}\text { Adjusted } \\
\mathrm{R}^{2}\end{array}$ & 0.0905 & 0.0737 & 0.0601 & 0.0634 & 0.0199 & 0.0258 & 0.0317 & 0.0266 \\
\hline $\mathrm{N}$ & 357 & 357 & 357 & 357 & 2968 & 2968 & 2968 & 2968 \\
\hline
\end{tabular}

From the salesperson salary distribution in enterprises with different R\&D intensity (Figure 1), we can know that the overall salary level of salespersons in enterprises with high R\&D intensity is higher than that in enterprises with low R\&D intensity, which shows that the corporate $R \& D$ investment matches with the salesperson human capital investment. Increasing salesperson human capital investment promotes the growth of export performance in both high and low R\&D intensity enterprises. Considering the marginal revenue of salespersons, which means the employee compensation, is higher in enterprises with high R\&D intensity than that in enterprises with low R\&D intensity, the compensation strategy of high R\&D intensity enterprises is relatively more competitive, which attracts and retains excellent sales with a higher level of knowledge and skills. As a result, the salespersons of enterprises with high R\&D intensity are more competitive than that of enterprises with low R\&D intensity, generating higher marginal product for enterprises with high R\&D intensity. In other words, inputting a unit of labor with the same value, salespersons of enterprises with higher R\&D intensity will create greater growth of export trade. It can be seen that enterprises with higher $\mathrm{R} \& \mathrm{D}$ intensity can improve their export performance to a greater extent by increasing the human capital investment in salespersons. 
a)

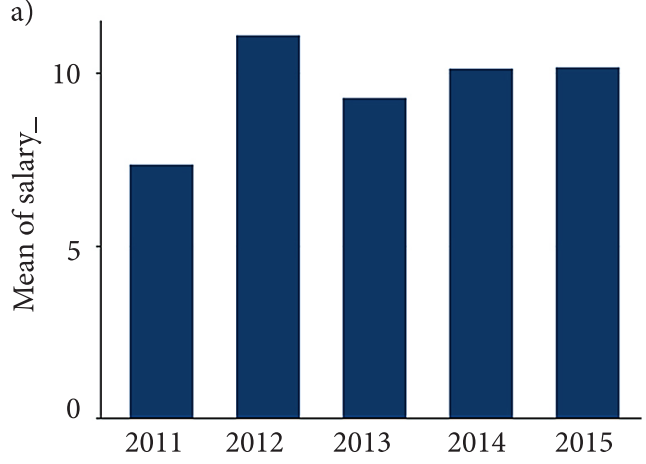

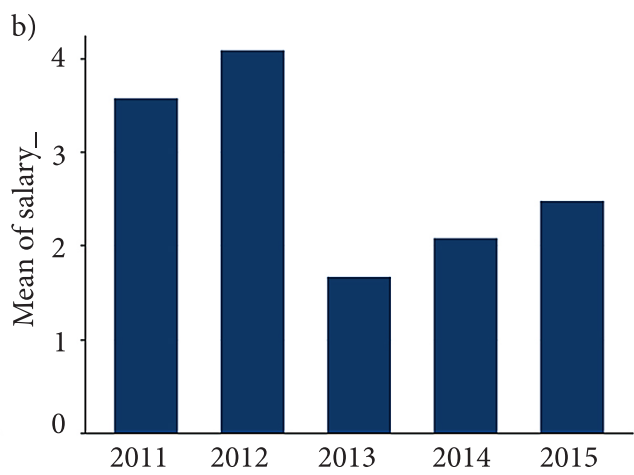

Figure 1. Salesperson salary distribution of enterprises with different R\&D intensity:

a) - distribution of high R\&D intensity enterprises;

b) - distribution of low R\&D intensity enterprises

\subsection{Impact analysis based on industry intensity heterogeneity}

The regression results in Table 7 show that the increase of export performance for every unit increase of salesperson human capital investment in technology-intensive industries is higher than that in labor-intensive industries. It is known that the products of technology-intensive enterprises are of higher technology intensity, the oriented customer base of which are also supposed to possess some product related expertise. Thus, the salespersons are ordered to have a certain level of professional knowledge and expertise, in order to efficiently grasp the technical information of the products, improve customer satisfaction, obtain more sales orders and promote enterprise export performance. As for the labor-intensive manufacturing enterprises, their products contain lower technical intensity, which requires a relatively lower knowledge level of the salespersons. Such companies tend to hire less educated low-cost staff and give them a unified full-time skills training, so as to increase the sales revenue and improve the export performance. Employee pay is industry-specific. The more technologyintensive the industry is, the higher the salaries of employees in the industry (Sullivan, 2010; Lagoa \& Suleman, 2016). Technology-intensive enterprises pay salespersons a higher salary than labor-intensive enterprises. Thus technology-intensive enterprises have competitive high pay to attract and retain excellent salespersons. Therefore, unit human capital investment of technology-intensive enterprise contributes more to the export performance.

The ratio of expenses to sales, which reflects the human Capital Investment II, shows a "positive U-shaped" distribution with the export performance of enterprises in both technology-intensive industries and labor-intensive industries. But the critical point of sales expenses rate of the technology-intensive enterprises is lower than that of the labor-intensive enterprises. That is, technology-intensive industries enter the stage of the positive impact of sales expenses rate on export performance earlier than labor-intensive industries, which is shown in Figure 2.

The marketing ability of enterprises has a positive impact on the degree of independent innovation. Furthermore, the improvement of independent innovation ability will promote 
the increase of technological progress rate and thus the productivity of enterprises, leading to the growth of the return of products in the market (Yalcinkaya, Calantone, \& Griffith, 2007). Due to the difference of technical added value and technical complexity of products between domestic market and overseas market, and the variation of replacement demand for products with different technology intensity in the overseas market, the enterprises will have different intensity of export learning effect (Munch \& Skaksen, 2008). Consequently, the

Table 7. Regression results of the impact of the salesperson human capital investment on the export performance of enterprises with different technology intensity

\begin{tabular}{|c|c|c|c|c|c|c|c|c|}
\hline \multicolumn{9}{|c|}{ Dependent variable: enterprise export performance (ee_) } \\
\hline & \multicolumn{4}{|c|}{ technology-intensive (non-manufacturing) } & \multicolumn{4}{|c|}{ labor-intensive (manufacturing) } \\
\hline $\begin{array}{c}\text { Inde- } \\
\text { pendent } \\
\text { variable }\end{array}$ & (1) & (2) & (3) & (4) & (5) & (6) & (7) & (8) \\
\hline \multirow{2}{*}{ salary_ } & $0.0009^{*}$ & & & $0.0009^{* *}$ & 0.0001 & & & $0.0002^{*}$ \\
\hline & $(0.0004)$ & & & $(0.0004)$ & $(0.0001)$ & & & $(0.0001)$ \\
\hline \multirow{2}{*}{$s r r_{-}$} & & 0.2040 & -1.1473 & -1.1675 & & $-0.1883^{* *}$ & $-0.3626^{\star *}$ & $-0.3705^{\star *}$ \\
\hline & & $(0.3344)$ & $(0.8115)$ & $(0.8078)$ & & $(0.0801)$ & $(0.1533)$ & $(0.1538)$ \\
\hline \multirow{2}{*}{$\operatorname{srr} 2_{-}$} & & & $4.5756^{*}$ & $4.7033^{\star}$ & & & $0.5556^{*}$ & $0.5692^{*}$ \\
\hline & & & $(2.5020)$ & $(2.5016)$ & & & $(0.3275)$ & $(0.3283)$ \\
\hline \multirow{2}{*}{ constant } & $0.4589^{\star * *}$ & $0.5023^{\text {***}}$ & $0.5657^{\star * *}$ & $0.4944^{* * *}$ & $0.2788^{\star * *}$ & $0.2910^{* * *}$ & $0.3000^{* * *}$ & $0.3024^{* * *}$ \\
\hline & $(0.1287)$ & $(0.1540)$ & $(0.1450)$ & $(0.1268)$ & $(0.0588)$ & $(0.0599)$ & $(0.0610)$ & $(0.0611)$ \\
\hline $\begin{array}{l}\text { Adjusted } \\
\mathrm{R}^{2}\end{array}$ & 0.0973 & 0.0724 & 0.1189 & 0.1280 & 0.0204 & 0.0419 & 0.0444 & 0.0464 \\
\hline $\mathrm{N}$ & 295 & 295 & 295 & 295 & 3030 & 3030 & 3030 & 3030 \\
\hline
\end{tabular}

a)

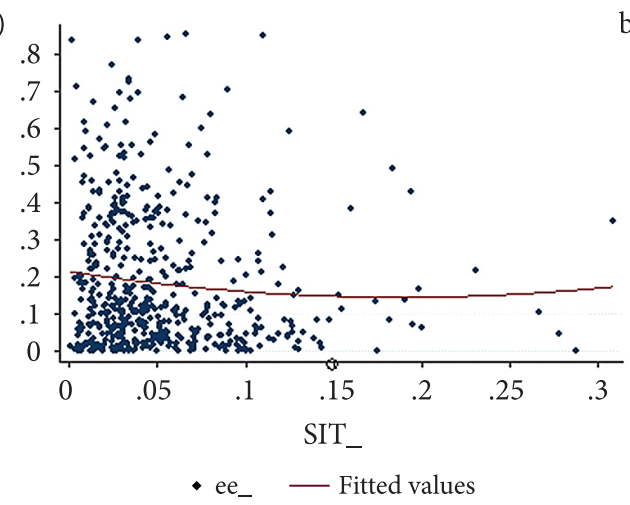

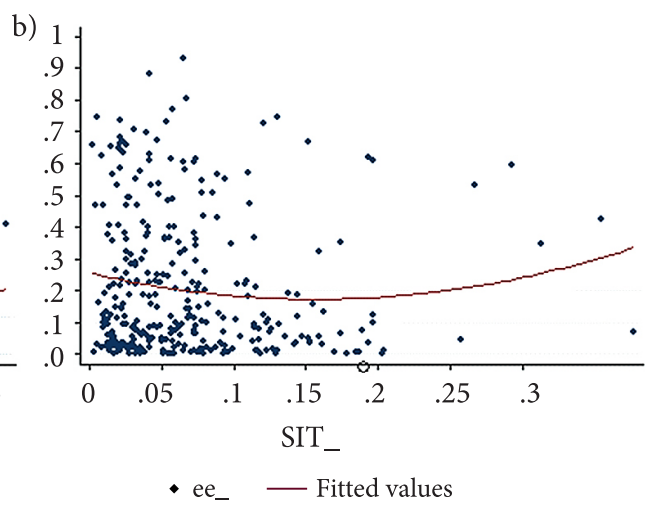

Figure 2. The relationship between sales expense ratio and export performance of enterprises with different technology intensity: a) - result of technology-intensive enterprises;

b) - result of labor-intensive enterprises 
investment in improving the knowledge of sales managers and salespersons, which is mainly the marketing expenses incurred by marketing programs, is supposed to increase. Compared with the labor-intensive enterprises, the products of technology-intensive enterprises own higher technical added value, the technical process of which is more complicated. Moreover, the overseas markets have a stronger demand for the upgrading of high technology-intensive products. There will be the more obvious performance of export learning effect in technology-intensive industries, so the technology-intensive enterprises will pay more attention to improving the salespersons' knowledge, skills, and marketing capabilities. The sales expenses raised by the investment in salespersons will increase the ability of independent innovation, and thus improve the productivity and export performance of the enterprises. Hence, the critical sales expenses rate of technology-intensive enterprises is lower than that of laborintensive enterprises. That is to say, the technology-intensive enterprises will have an earlier positive impact on the export performance.

\section{Conclusions}

This study examines the linkage between salesperson human capital investment and export performance for Chinese A-share listed enterprises during the period 2011-2015. The human capital investment on salespersons is divided into the human capital investment I on overall salespersons, represented by the salesperson salary, and the human capital investment II on sales managers, calculated by the ratio of expenses to sales. Based on the perspectives of R\&D intensity and technology intensity of the industries to which they belong, we respectively examine the impact of the human capital investment I and the human capital investment II on the export performance of enterprises.

In general, the empirical results suggest that the salesperson human capital investment I improves the growth of the export performance, while the salesperson human capital investment II shows a "positive U-shaped" distribution with the export performance. The positive influence of human capital investment I can be attributed to the decisive role of salaries in determining the sales performance of salespersons. As for the "positive U-shaped" relationship between the human capital investment II and the export performance, it can be explained as a trade-off between the sales expenses and the effectiveness of marketing programs. In the early stage of implementing the marketing programs, the growth of human capital investment, which results in the increase of sales expense rate, will not cause the export performance to increase. With marketing program developing, the sales expense rate will reach the critical point. And the ever-increasing sales expense rate, reflecting the skill levels of sales managers, will have a positive impact on the export performance.

Moreover, we go one step further and examine the different impacts of the salesperson human capital investment on the export performance under different R\&D intensity and technology intensity. Our results show that increasing the salary of the ordinary salesperson has a stronger positive effect on the promotion of export performance in enterprises with higher R\&D intensity. Thus the R\&D intensity of enterprises should match the salesperson salary. Enterprises with higher R\&D intensity should provide a higher salary for salespersons, which does well to boost the enthusiasm of the salespersons and bring higher export 
trade volume to the enterprises. The human capital investment of the overall salespersons of the technology-intensive enterprises has a stronger positive effect on the export performance than that of the labor-intensive enterprises. And the critical point of the relationship between the sales expenses rate and the export performance is lower in the technologyintensive enterprises, which means that the technology-intensive enterprises will earlier enter the positively affecting stage for the human capital investment of sales managers and the export performance.

This study is meaningful because of its application value for export enterprises. First, enterprises should pay attention to employing sales managers with high skill levels and extensive experience in the development of overseas markets. Export marketing programs with market adaptabilities play an important role in opening up new markets and increasing the demand of overseas consumers. Highly-skilled sales managers have the capacity to formulate successful marketing programs, which advance the export growth. Second, a reasonable salary management system for salespersons is supposed to be constructed. The results of this study reveal that salesperson salary has a significant positive relationship with the export performance of enterprises, while the promotion of compensation needs to be guaranteed by a reasonable salary policy. Enterprises are supposed to ensure the internal and external fairness of the salary system, and reasonably adjust the salary level to match the corresponding properties such as the R\&D intensity, the technology intensity and whether the company is a start-up or mature. Third, training for salespersons needs to be assigned a higher priority. Overseas markets have strong demand for rapid product replacement, especially for the enterprises with high technology intensity. Therefore, enterprises should attach importance to improving the knowledge and skill levels of salespersons, cultivating their marketing abilities and expanding the learning effects in exports, so as to meet the changing needs of consumers and promote the growth of export performance.

Our research has some limitations. Based on the human capital theory, human capital investment is supposed to cover many implications, including the cost of education, health improvement and so on. However, the detail data of enterprise expenditure on these items are not publicly available. Thus we choose employee salary and sales expense rate to indicate the human capital investment. The future research might be expanded into theses perspectives, taking into account the human capital investment in education, training, health improvement and other areas and their impacts on export performance.

\section{Funding}

This work was supported by The Education Department of Henan Province under Grant (No. 2018-ZZJH-457) and Ministry of Education of the People's Republic of China under Grant (No. 15XJC790006).

\section{Disclosure statement}

The authors declare that we have no competing financial, professional, or personal interests from other parties. 


\section{References}

Akdeniz, M. B., Gonzalez-Padron, T., \& Calantone, R. J. (2010). An integrated marketing capability benchmarking approach to dealer performance through parametric and nonparametric analyses. Industrial Marketing Management, 39(1), 150-160. https://doi.org/10.1016/j.indmarman.2008.05.002

Akgul, Z. (2015). Modeling, empirics and policy implications of firm heterogeneity in international trade. West Lafayette: Purdue University.

Aw, B. Y., \& Hwang, A. R. M. (1995). Productivity and the export market: a firm-level analysis. Journal of Development Economics, 47(2), 313-332. https://doi.org/10.1016/0304-3878(94)00062-H

Axinn, C. N. (1988). Export performance: do managerial perceptions make a difference? International Marketing Review, 5(2), 61-71. https://doi.org/10.1108/eb008353

Babakus, E., Cravens, D. W., Grant, K., Ingram, T. N., \& Laforge, R. W. (1996). Investigating the relationships among sales, management control, sales territory design, salesperson performance, and sales organization effectiveness. International Journal of Research in Marketing, 13(4), 345-363. https://doi.org/10.1016/S0167-8116(96)00016-X

Ballot, G., Fakhfakh, F., \& Taymaz, E. (2001). Firms' human capital, R\&D and performance: a study on French and Swedish firms. Labour Economics, 8(4), 443-462.

https://doi.org/10.1016/S0927-5371(01)00038-0

Bapna, R., Langer, N., Mehra, A., Gopal, R., \& Gupta, A. (2013). Human capital investments and employee performance: an analysis of it services industry. Management Science, 59(3), 641-658. https://doi.org/10.1287/mnsc.1120.1586

Barrio-Castro, T. D., López-Bazo, E., \& Serrano-Domingo, G. (2002). New evidence on international R\&D spillovers, human capital and productivity in OECD. Economics Letters, 77(1), 41-45. https://doi.org/10.1016/S0165-1765(02)00090-3

Becker, G. S. (1962). Investment in human capital: a theoretical analysis. Journal of Political Economy, 70(5), 9-49. https://doi.org/10.1086/258724

Black, S. E., \& Lynch, L. M. (1996). Human-capital investments and productivity. The American Economic Review, 86(2), 263-267.

Blundell, R., Dearden, L., Meghir, C., \& Sianesi, B. (1999). Human capital investment: the returns from education and training to the individual, the firm and the economy. Fiscal Studies, 20(1), 1-23. https://doi.org/10.1111/j.1475-5890.1999.tb00001.x

Bowlus, A. J., \& Robinson, C. (2012). Human capital prices, productivity, and growth. The American Economic Review, 102(7), 3483-3515. https://doi.org/10.1257/aer.102.7.3483

Caselli, M. (2014). Trade, skill-biased technical change and wages in Mexican manufacturing. Applied Economics, 46(3), 336-348. https://doi.org/10.1080/00036846.2013.848033

Cavusgil, S. T., \& Zou, S. (1994). Marketing strategy-performance relationship: an investigation of the empirical link in export market ventures. The Journal of Marketing, 58(1), 1-21. https://doi.org/10.2307/1252247

Chang, C. F., Wang, P., \& Liu, J. T. (2016). Knowledge spillovers, human capital and productivity. Journal of Macroeconomics, 47, 214-232. https://doi.org/10.1016/j.jmacro.2015.11.003

Chng, D. H. M., Shih, E., Rodgers, M. S., \& Song, X. B. (2015). Managers' marketing strategy decision making during performance decline and the moderating influence of incentive pay. Journal of the Academy of Marketing Science, 43(5), 629-647. https://doi.org/10.1007/s11747-014-0401-x

Contractor, F. J., \& Mudambi, S. M. (2008). The influence of human capital investment on the exports of services and goods: an analysis of the top 25 services outsourcing countries. Management International Review, 48(4), 433-445. https://doi.org/10.1007/s11575-008-0025-9 
Crook, T. R., Todd, S. Y., Combs, J. G., Woehr, D. J., \& Ketchen, J. D. J. (2011). Does human capital matter? A meta-analysis of the relationship between human capital and firm performance. Journal of Applied Psychology, 96(3), 443-456. https://doi.org/10.1037/a0022147

Delgado, M. A., Farinas, J. C., \& Ruano, S. (2002). Firm productivity and export markets: a nonparametric approach. Journal of International Economics, 57(2), 397-422. https://doi.org/10.1016/S0022-1996(01)00154-4

Demmel, M. C., Máñez, J. A., Rochina-Barrachina, M. E., \& Sanchis-Llopis, J. A. (2017). Product and process innovation and total factor productivity: evidence for manufacturing in four Latin American countries. Review of Development Economics, 21(4), 1341-1363. https://doi.org/10.1111/rode.12323

Engel, D., \& Procher, D. (2012). Export, FDI and firm productivity. Applied Economics, 44(15), 19311940. https://doi.org/10.1080/00036846.2011.556591

Georgiadis, A., \& Pitelis, C. N. (2016). The impact of employees' and managers' training on the performance of small-and medium-sized enterprises: evidence from a randomized natural experiment in the UK service sector. British Journal of Industrial Relations, 54(2), 409-421. https://doi.org/10.1111/bjir.12094

Griffith, D. A., \& Hoppner, J. J. (2013). Global marketing managers: improving global marketing strategy through soft skill development. International Marketing Review, 30(1), 21-41. https://doi.org/10.1108/02651331311298555

Hawes, J. M., Jr, D. W. J., Schlacter, J. L., \& Wolfe, W. G. (1995). Selling and sales management in action examining the bases utilized for evaluating salespeoples' performance. Journal of Personal Selling \& Sales Management, 15(4), 57-65.

Helm, R., \& Gritsch, S. (2014). Examining the influence of uncertainty on marketing mix strategy elements in emerging business to business export-markets. International Business Review, 23(2), 418-428. https://doi.org/10.1016/j.ibusrev.2013.06.007

Holland, S. B. (2017). Firm investment in human health capital. Journal of Corporate Finance, 46, 374390. https://doi.org/10.1016/j.jcorpfin.2017.08.003

Kadochnikov, S. M., \& Fedyunina, A. A. (2017). The impact of financial and human resources on the export performance of Russian firms. Economic Systems, 41(1), 41-51. https://doi.org/10.1016/j.ecosys.2016.11.001

Koh, A. C., \& Robicheaux, R. A. (1988). Variations in export performance due to differences in export marketing strategy: implications for industrial marketers. Journal of Business Research, 17(3), 249258. https://doi.org/10.1016/0148-2963(88)90057-4

Kozioł, L., Kozioł, W., Wojtowicz, A., \& Pyrek, R. (2014). An outline of a compensation system based on human capital theory is. Procedia - Social and Behavioral Sciences, 148, 551-558. https://doi.org/10.1016/j.sbspro.2014.07.078

Kumar, A., \& Kober, B. (2012). Urbanization, human capital, and cross-country productivity differences. Economics Letters, 117(1), 14-17. https://doi.org/10.1016/j.econlet.2012.04.072

Lagoa, S., \& Suleman, F. (2016). Industry- and occupation-specific human capital: evidence from displaced workers. International Journal of Manpower, 37(1), 44-68. https://doi.org/10.1108/IJM-11-2013-0257

Leonidou, L. C., Katsikeas, C. S., \& Samiee, S. (2004). Marketing strategy determinants of export performance: a meta-analysis. Journal of Business Research, 55(1), 51-67. https://doi.org/10.1016/S0148-2963(00)00133-8

Melitz, M. J. (2003). The impact of trade on intra-industry reallocations and aggregate industry productivity. Econometrica, 71(6), 1695-1725. https://doi.org/10.1111/1468-0262.00467 
Miller, S. M., \& Upadhyay, M. P. (2000). The effects of openness, trade orientation, and human capital on total factor productivity. Journal of Development Economics, 63(2), 399-423. https://doi.org/10.1016/S0304-3878(00)00112-7

Morgan, N. A., Katsikeas, C. S., \& Vorhies, D. W. (2012). Export marketing strategy implementation, export marketing capabilities, and export venture performance. Journal of the Academy of Marketing Science, 40(2), 271-289. https://doi.org/10.1007/s11747-011-0275-0

Munch, J. R., \& Skaksen, J. R. (2008). Human capital and wages in exporting firms. Journal of International Economics, 75(2), 363-372. https://doi.org/10.1016/j.jinteco.2008.02.006

Olley, G. S., \& Pakes, A. (1992). The dynamics of productivity in the telecommunications equipment industry. Econometrica, 64(6), 1263-1297. https://doi.org/10.2307/2171831

Olson, E. M., Slater, S. F., Hult, G. T. M., \& Kai, M. O. (2018). The application of human resource management policies within the marketing organization: the impact on business and marketing strategy implementation. Industrial Marketing Management, 69, 62-73.

https://doi.org/10.1016/j.indmarman.2018.01.029

Onkelinx, J., Manolova, T. S., \& Edelman, L. F. (2016). The human factor: investments in employee human capital, productivity, and SME internationalization. Journal of International Management, 22(4), 351-364. https://doi.org/10.1016/j.intman.2016.05.002

Pastore, F. (2013). Productivity, investment in human capital and the challenge of youth employment. Journal of Education Policy, 28(3), 404-405. https://doi.org/10.1080/02680939.2012.724601

Rialp-Criado, A., \& Rialp-Criado, J. (2018). Examining the impact of managerial involvement with social media on exporting firm performance. International Business Review, 27(2), 355-366. https://doi.org/10.1016/j.ibusrev.2017.09.003

Ricci, L. A., \& Trionfetti, F. (2012). Productivity, networks, and export performance: evidence from a cross-country firm dataset. Review of International Economics, 20(3), 552-562. https://doi.org/10.1111/j.1467-9396.2012.01038.x

Rodrigue, J. (2014). Multinational production, exports and aggregate productivity. Review of Economic Dynamics, 17(2), 243-261. https://doi.org/10.1016/j.red.2013.08.002

Ruzo, E., Losada, F., Navarro, A., \& Díez, J. A. (2011). Resources and international marketing strategy in export firms: implications for export performance. Management Research Review, 34(5), 496-518. https://doi.org/10.1108/01409171111128698

Schmid, S., \& Altfeld, F. (2018). International work experience and compensation: is more always better for CFOs? European Management Journal, 36(4), 530-543. https://doi.org/10.1016/j.emj.2017.11.001

Schultz, T. W. (1961). Investment in human capital. The American Economic Review, 51(1), 1-17.

Slaughter, S. A., Ang, S., \& Boh, W. F. (2007). Firm-specific human capital and compensation organizational tenure profiles: an archival analysis of salary data for it. Human Resource Management, 46(3), 373-394. https://doi.org/10.1002/hrm.20169

Söderling, L. (2000). Dynamics of export performance, productivity and real effective exchange rate in manufacturing: the case of Cameroon. Journal of African Economies, 9(4), 411-429. https://doi.org/10.1093/jae/9.4.411

Sousa, C. M., Ruzo, E., \& Losada, F. (2010). The key role of managers' values in exporting: influence on customer responsiveness and export performance. Journal of International Marketing, 18(2), 1-19. https://doi.org/10.1509/jimk.18.2.1

Sullivan, P. (2010). Empirical evidence on occupation and industry specific human capital. Labour Economics, 17(3), 567-580. https://doi.org/10.1016/j.labeco.2009.11.003

Toole, A. A., \& Czarnitzki, D. (2009). Exploring the relationship between scientist human capital and firm performance: the case of biomedical academic entrepreneurs in the SBIR program. Management Science, 55(1), 101-114. https://doi.org/10.1287/mnsc.1080.0913 
Turner, C., Tamura, R., \& Mulholland, S. E. (2013). How important are human capital, physical capital and total factor productivity for determining state economic growth in the United States, 18402000? Journal of Economic Growth, 18(4), 319-371. https://doi.org/10.1007/s10887-013-9090-4

Volonté, C., \& Gantenbein, P. (2016). Directors' human capital, firm strategy, and firm performance. Journal of Management \& Governance, 20(1), 115-145. https://doi.org/10.1007/s10997-014-9304-y

Wang, Y., \& Yao, Y. (2003). Sources of China's economic growth 1952-1999: incorporating human capital accumulation. China Economic Review, 14(1), 32-52. https://doi.org/10.1016/S1043-951X(02)00084-6

Yalcinkaya, G., Calantone, R. J., \& Griffith, D. A. (2007). An examination of exploration and exploitation capabilities: implications for product innovation and market performance. Journal of International Marketing, 15(4), 63-93. https://doi.org/10.1509/jimk.15.4.63

Yang, C. H., \& Chen, Y. H. (2012). R\&D, productivity, and exports: plant-level evidence from Indonesia. Economic Modelling, 29(2), 208-216. https://doi.org/10.1016/j.econmod.2011.09.006

Youndt, M. A., Snell, S. A., Dean, J. W., \& Lepak, D. P. (1996). Human resource management, manufacturing strategy, and firm performance. Academy of Management Journal, 39(4), 836-866. https://doi.org/10.5465/256714

Zeriti, A., Robson, M. J., Spyropoulou, S., \& Leonidou, C. N. (2014). Sustainable export marketing strategy fit and performance. Journal of International Marketing, 22(4), 44-66. https://doi.org/10.1509/jim.14.0063 